\title{
RETENTION AND BRAIN DRAIN OF ACADEMIC STAFF IN HIGHER INSTITUTION IN NIGERIA: A CASE STUDY OF UNIVERSITY OF CALABAR
}

\author{
ANOKYE, SAMPSON AHMAD, OKRI JOHN ARIKPO AND ADIE EMMANUEL A.
}

(Received 25, September 2017; Revision Accepted 28, November 2019)

\begin{abstract}
Since the inception of higher education, it has been observed that academic staff has been catalysts who have been propellers of the development of higher education through teaching (lecturing), learning, researching and community development when necessary tools and materials were provided to enhance effective teaching and learning of students who invariably become the leaders of tomorrow. But for some decades now, the higher institutions have been criticized for not providing students what it takes so that they can compete favourably with their counterparts in international markets. This unwanted assumption has happened as a result of mismanagement of academic staff in terms of staff development, proper incentives, infrastructure decay such as office accommodation and motivation, proper remuneration, delay in payment of salaries, staff training and retraining, fringe benefits and promotion when due. Based on the stated facts, highly qualified, competent, dedicated, diligent, skilled academic staff always find their way out to where their needs would be met rapidly. This movement of academic staff in tertiary institutions have negative effect on the institution and also the students in that they would be no immediate replacement to fill the vacuum and this can affect their academic performance and expert. If rapid and pragmatic approach for retention is not given proper attention, the academic staff leave the system to seek for a place where there are better conditions of service possibly in overseas countries such as the United Kingdom. If they find that there is disparity, they leave where they were for where better conditions of service are available. This paper suggests various ways where retention of academic staff would be given proper attention to curtail brain drain to the bearest minimum.
\end{abstract}

KEYWORDS: Retention, brain drain and academic staff

\section{INTRODUCTION}

In the university system, the academic staff play very important role to the sustainability and development of the University. Apart from lecturing, researching and community development, Aghenta (1998) was very sure to state that lecturers or academic staff educate and develop students to the point of judging them fit for award of degrees, diplomas and certificates. Mgbekem (2004) revealed additionally that academic staff participates in decision making by attending departmental meetings, faculty board meetings and senate meetings where plans and programmes of the University are drawn up. Through the resources made available to

Anokye, Sampson Ahmad, Department of Educational Administration and Planning University of Calabar Calabar, Nigeria.

Okri John Arikpo, Department of Science Education University of Calabar Calabar, Nigeria.

Adie Emmanuel A., Department of Science Education University of Calabar Calabar, Nigeria. 
academic staff, teaching and learning can be achieved and students are prepared as finished products for the task of serving their societies. Mgbekem (2004) opined that academic staff compliment the work of Top Management of the University pyramid. While the Top Management makes policies, academic staff execute or implement the policies at the lower rung of the pyramid. In effect, academic staff are the crux of the University Education (Mgbekem, 2004).

From the above revelation, the functions of academic staff in the University system are very unique in that no university can achieve her objectives such as the development of man power and middle manpower development of the nation without them. Akuegwu (2005) saw this hence contributed his thought that the educational system at the tertiary level is seen as a tool by which a national identity and civil society are built through shared value and a commitment to a common goal, and this has been achieved through committed, dedicated, diligent, loyal, competent and sound academic staff. Cripps (2001) on the other hand pointed out that tertiary institutions play a key role in social and cultural development. Again this cannot be achieved without loyal academic staff. The question that needs cogent answer is who are those who are involved in the tertiary institutions work to achieve the responsibility as a nation builder? The government seeing these important functions of tertiary education goes all out to employ academic staff to man all the faculties as enumerated by (Mgbekem, 2004). But it is observed that if proper management of academic staff is not given full support, their attitude to work and work performance cannot be assured (Anokye, 2011) and this will give rise to brain drain. While other academic staff will like to continue to stay in the university, others will like to leave and go to another place that would give proper attention to the academic staff conditions of service because his/her services are needed. The paper discusses brain drain, factors causing the brain drain, factors which might offset the brain drain in higher education in the UK, demerits of brain drain, effects of brain drain on higher education and retention of academic staff.

\section{BRAIN DRAIN AND ITS IMPORTANCE}

Brain drain is the movement of skilled professionals within Africa as well as from Africa to the developed world in search of more lucrative jobs and opportunities. This has come to stay as a result of the home country inability to provide the necessary conditions of service for the workers. In Africa, there was massive move of academic staff to United Kingdom in search of jobs. Nunn (2005) reported that the United Kingdom has for several years operated differentiated immigration policies designed to attract some skilled workers. Being that United Kingdom benefits from the Africa immigrant to the United Kingdom, Nunn (2005) said that immigration laws pertaining to African immigrants are strengthened in terms of the general scale of migration to work in the United Kingdom. According to Nunn's report, home office records show that in 2002, 119, 000 people entered the United Kingdom on work permits. From that time till date, brain drain has increased astronomically in that the various governments in Africa has not been able to fulfil their promise to the academic staff. In Nigeria, academic staff embark on strikes to press home their demands.

This goes to show that brain drain has become a phenomenon that has happened to some Africa countries. According to Nunn (2005) Africa acts as a perfect case study for the general thesis about development, skills and brain drain. To him, the continent has witnessed decades of wasted development potential and in places suffers problems of extreme poverty and lack of both human and institutional capacity. Nunn (2005) reported that even relatively developed African state like Nigeria, demonstrates a lack of capacity to meet demand for education. It was based on this that Oyekanmi (2005) pointed what Professor Babs Fafunwa a renowned educationist and one time Minister of Education once said, that 40 percent of Nigeria's annual budget should go to education. He said the importance of education as a builder of its citizens is so important that it must not be toyed with. Quoting Professor Babs Fafunwa "what are we developing for if you have good education, your health problem will be improved because people will be more enlightened on what to do when they are sick, our agriculture will improve if we have people who are well educated than when we just have illiterate" (p.46). But it is unfortunate that Nigeria budgetary allocation yearly for education is nothing to write home about. United Nations Educational, Scientific and Cultural Organization (UNESCO) has set a benchmark of $26 \%$ budgetary allocation for education for every member country in order to attain its vision 20:20:20 and believing that if any member country like Nigeria has adhered to, then things would work well in education sector. On the contrary, some Nigerians have strongly kicked against N426.536b (representing only 
$8.7 \%$ of the total budget) proposed to service the education sector. Meaning that it was too much (Editorial, 2013). By this statistics, the education sector ought not to have gotten less than 1.27 4 trn out of the total budgeted N4.9trn. The Editorial (2013) gave a strong reason that education is the oil that greases the wheel of national socio-economic development coupled with the drive need to revitalize the oiling sector in Nigeria justifies why the $26 \%$ minimum allocation can never be said to be outrageous.

While the $8.7 \%$ education budgetary allocation is the Federal Government's best in recent past,
Editorial (2013) pointed out that it must be kingly noted, it is still comparatively very infinitesimal even as UNESCO's benchmark is $26 \%$. While other African countries have adhered to the UNESCO's benchmark of $26 \%$ budgetary allocation for Education, Nigeria is still crawling, hence it has affected Education sector to do better than to take care of tertiary education. This paper has presented the budgetary allocation for member countries of the United Nations to see which countries have been able to adhere to UNESCO's proposal of 26 percent budgetary allocation.

\section{Below is the Annual Budgetary allocation by some selected countries (source world bank 2016 - 2018)}

\begin{tabular}{|l|l|l|l|}
\hline $\mathbf{S} / \mathbf{N}$ & Country & Year & $\begin{array}{l}\text { Budgetary Allocation } \\
\text { to education (in \%) }\end{array}$ \\
\hline 1. & Bukina faso & 2017 & 12.0 \\
\hline 2. & Cameroon & 2017 & 15.5 \\
\hline 3. & Burundi & 2017 & 20.4 \\
\hline 4. & Congo & 2017 & 11.7 \\
\hline 5. & Afghanistan & 2017 & 15.7 \\
\hline 6. & Ghana & 2017 & 20.1 \\
\hline 7. & South Africa & 2018 & 18.9 \\
\hline 8. & Norway & 2016 & 16.0 \\
\hline 9. & UAE(United Arab Emirate) & 2016 & 13.8 \\
\hline 10. & Czech Republic & 2016 & 14.2 \\
\hline 11. & Cote divoire & 2018 & 18.5 \\
\hline 12. & Chile & 2017 & 21.3 \\
\hline 13. & Mexico & 2017 & 17.9 \\
\hline 14. & Lesotho & 2018 & 13.5 \\
\hline 15. & Sierra Leone & 2018 & 30.2 \\
\hline 16. & Senegal & 2017 & 21.6 \\
\hline 17. & Rwanda & 2018 & 10.8 \\
\hline 18. & Nigeria & 2019 & 7.05 \\
\hline
\end{tabular}

Source: Education Affairs Vol. No. 3 P.6

With this budgetary allocation for education, the same budgetary allocation is also used to fund University system.

University Education financing is an essential function of University administrators. In considering educational financing, Mgbekem (2004) mentioned that much attention must be given to budgeting and allocation of resources to education. Mgbekem (2004) itemized the following as reflected in the University budget.

1. Staff salaries and allowances in the Universities.
2. Recurrent expenses on purchases for academic running.

3. Instructional equipment

4. Rapid to building and equipment

5. Express on public occasions, e.g convocation ceremony.

6. New classroom blocks including lecture theatres and auditoria.

7. Acquisition of land for expansion of the campus.

8. Maintenance of the University forum

9. Books for the library 
10. Hotel/accommodation and maintenance

The National Universities commission sends allocations to the respective Federal Universities and institutions to pay for goods and services (Mgebekem, 2004).

With all these, it becomes burdensome for the universities to do what they are expected to do to achieve its objectives as stated by National Policy on Education (1998:22) which emphasizes that University Education shall make optimum contribution to National Development. The policy opined that the main objective for establishing university Education in Nigeria is basically for national development.

With these myriads of commitments which involve financing, any shortfall of these to the academic staff welfare in terms of housing loan, vehicles advance, vehicle refurnishing loan, furniture advance, university rental accommodations, in-service training or staff development programmes, sponsorship for staff, sabbatical leave and promotion for staff, the academic staff finds another place where these abound as supported by social comparative theory which states that a worker compares himself with the counterparts who enjoys more facilities not forgotten that they have the same qualifications.

If the conditions of service are not favourable, the academic staff leave where he/she is working to any other country where his services are needed. And, this is called brain drain. The African nations like to work in the United Kingdom as a result of the availability of chances to work there. The table below shows the extent Africans migrate to the United Kingdom for employment.

\section{BRAIN DRAIN AND HIGHER EDUCATION IN THE UK AND AFRICA}

This Table shows Academic Staff in UK by Nationality.

\begin{tabular}{|l|l|l|}
\hline Continent totals & $\begin{array}{l}\text { No. of staff in } \\
\text { UK Headcount }\end{array}$ & of Total \\
\hline Africa & 1339 & $0.9 \%$ \\
\hline Asia & 5363 & $3.7 \%$ \\
\hline Carribbean & 147 & $0.1 \%$ \\
\hline Central and Latin American & 514 & $0.3 \%$ \\
\hline EU & 12834 & $8.7 \%$ \\
\hline EU country & 17 & $0.0 \%$ \\
\hline Europe (Non -Eu) & 2078 & $1.4 \%$ \\
\hline Middle East & 662 & $0.5 \%$ \\
\hline IN. America (US and Canada & 3053 & $2.1 \%$ \\
\hline Australia and Oceans & 1791 & $1.2 \%$ \\
\hline UK Extra Territorial & 58 & $0.0 \%$ \\
\hline Stateters & 9 & $0.0 \%$ \\
\hline Uknowu & 6107 & $4.2 \%$ \\
\hline Total & $\mathbf{3 3 9 7 2}$ & $\mathbf{2 3 . 1 \%}$ \\
\hline AD Staff UK Total & 146877 & \\
\hline
\end{tabular}

Source: Higher Education Statistics Agency 
The Table below shows academic staff in UK with African Nationalities,

\begin{tabular}{|l|l|}
\hline Country/ Nationality & No. of staff \\
\hline Algeria & 140 \\
\hline Angola & 10 \\
\hline Benin & 5 \\
\hline Botswana & 5 \\
\hline Cameroon & 45 \\
\hline Central African Republic & 6 \\
\hline Chad & 5 \\
\hline Congo (Democratic Republic) & 10 \\
\hline Congo (People's the public) & 5 \\
\hline Djibouti & 11 \\
\hline
\end{tabular}

Source: Nunn, Alex Report to the Ani and NATFHE

The Table below shows Brain Drain and Higher Education in the UK and Africa

\begin{tabular}{|c|c|}
\hline Country & No. of staff \\
\hline Egypt & 129 \\
\hline Eritrely & 4 \\
\hline Ercopia & 29 \\
\hline Gabon & 1 \\
\hline Gambia & 8 \\
\hline Ghana & 83 \\
\hline Guinea & 1 \\
\hline Guinea -Bassans & 2 \\
\hline Ivory loan & 7 \\
\hline Kenya & 53 \\
\hline Lesotho & 1 \\
\hline Hibya & 33 \\
\hline Malaise & 16 \\
\hline Mauritania & 9 \\
\hline Mauritius & 88 \\
\hline Morocco & 31 \\
\hline Mozambique & 4 \\
\hline Namibia & 2 \\
\hline Nigeria & 153 \\
\hline Rounds & 1 \\
\hline Seregle & 6 \\
\hline Sierra Leone & 25 \\
\hline Somalia & 5 \\
\hline South Africa & 268 \\
\hline Sudden & 44 \\
\hline Swaziland & 2 \\
\hline Tanzania & 13 \\
\hline Togo & 2 \\
\hline Turning & 22 \\
\hline Ugara & 21 \\
\hline Zambia & 33 \\
\hline Zimbabwe & 77 \\
\hline Burkina & 1 \\
\hline
\end{tabular}

Source: Higher Education Statistics 
The Tables shown above are the indications of brain drain in Africa which take places in UK in the name of making life better for individual who wants to develop maximally but not to be stagnant, like what is obtained in African status and were in the Education sector were in the Education Sector in UK.

\section{RETENTION OF ACADEMIC STAFF}

From a trade Union perspective, retention policies are by far the most desirable. Such policies address the core push factors, they include addressing issues of poor quality governance, political regression and equitable economic development for cohesive societies. In the specific case of academics, these policies include investing in research and teaching infrastructure, expanding and promoting academic freedom. Measures also include addressing pay and terms and conditions differentials, workers' rights and strengthening the power of collective representation and bargaining through strengthening trades union. Logan (2000) made known a strong point such as benefits for household dependents, academic freedom (depoliticized academic environment) and a clearly defined and transparent structure of reward for merit. Nunn's report (2005) suggested that inrestiment in key services and infrastructure, the promotion of workers' rights and better salaries and terms and conditions in developing countries would protect against the more damaging inputs of skilled migration (ICFTU, 2004b).

Effective enforcement of existing charters and declarations of rights for migrants and all workers would be useful in retaining skilled workers in developing countries.

\section{EFFECTS OF BRAIN DRAIN ON HIGHER EDUCATION}

Academic staff in higher institutions are specialists in nature. In that they have acquired specialized knowledge that not everyone has acquired it. These specialized fields are doctors, engineers, accountants, mathematicians, lawyers and computer scientists among others who are employed to lecture in the higher institutions. Sometimes, it is always very difficult to fill the vacuum when the said discipline becomes vacant. While these specialized academic staff were around with their students, they created a great impact on the students hence such act changed the mind-set or the academic perception of the students to do better. Why? The academic staff knew the course contents and their lecturing was exemplary. If such academic staff planned to leave for a "greener pasture", one way or the other, it affects the students who were studying under them. Since the course has not gotten enough specialized and competent lectures like Mr. X, The students begin to dwindle in knowledge.

This brain drain happened in Ghana some years ago as a result of Ghana government's inability to cater for the academic staff in terms of payment of better salaries and other fringe benefits as compared with their fellow counter parts in, Nigeria which they preferred to sojourn to lecture. When this happened, the higher institutions in Ghana became porous in their academic work and this affected the students' performance in that the best brains of the academic staff had left the country.

When FIt. Lieutenant Jerry Rawlings became the Head of State, later the President of Ghana he had to do all he could to return most of the academic staff with better conditions of service.

From the above one can see that the management of higher institutions should have competent, Gods fearing and dedicated management staff to manage the affairs of higher education in Africa.

It is widely acknowledged that human, social and institutional capacity are central to successful development with education being a key component in building their capacity (Nunn, 2005). And this is exactly what the former President Jerry Rawlings saw and decided to take a bold step to bring most of the Ghanaian academic staff to Ghana.

Ideally, skilled labour is of a crucial importance for developing countries to overcome the social and institutional barriers to successful to development. In addition to this Nunn (2005) reported that most contemporary economic theories of growth highlight the key importance of skills to economic performance and development potential hence when these skills are eluded as a result of brain drain then there is no economic performance and development potential.

In this context, the loss of skilled labour as a result of brain drain is of vital importance for development and development potential. For example, the loss of teachers (Academic staff) undermines the ability of University Education System to function to achieve its objectives of teaching (lecturing), researching and community 
development and the students on the other hand cannot measure up with their counterparts in other world where there is no brain drain among the academic as a result of proper management of academic staff.

\section{CONCLUSION}

This paper discussed at length brain drain which extended to the academic staff. It revealed that academic staff compare themselves with their counterparts in other universities in and outside their domain and see if the conditions do not merit, they take a decision to leave the university they are employed for preferably universities in UK where high skilled academic staff are not toyed with. The discussion of retention was taken in high, esteem, in that if an academic staff is not properly remunerated and other things done to make him/her stay, he will embark on brain drain which can affect the development of the home country and the universities at large.

\section{RECOMMENDATION}

It is therefore suggested that the administrators or managers of the universities should do all they can to retain the academic stafffrom leaving in that one way or the other, it will affect the growth and development of the university, invariably affecting the future generations who would be the leaders tomorrow.

\section{REFERENCES}

Aghenta, J. A., 1998. Basic general management. Functions in studies in Educational Planning (SEPA) vol. 1, No. 2.

Akuegwu, B. A., 2005. Administrative factor, job-related variables and academic staff job performance in tertiary institutions in Imo State, Nigeria. Unpublished Ph.D Thesis, University of Calabar, Nigeria.

Anokye, S. A., 2011. Staff development practices, attitude to work and work performance among academic staff in tertiary institutions in Ghana. Unpublished Ph.D Thesis, University of Calabar, Nigeria.

Cripps, S., 2001. Higher Education in South Africa. Bulletin of Association of Commonwealth universities.

ICFTU, 2004. Retention of academic staff in Alex Nunn. The "brain drain' academic and skilled migration to the UK and its impacts on Africa, April 2005.

Logan, P. K., 2000, Retention of academic staff in Alex Nunn. The 'brain drain' academic and skilled migration to the UK and its impacts on Africa, April 2005.

Mgbekem, S. J. A., 2004. Management of University Education in Nigeria.

Nunn, A., 2005. The 'brain drain' academic and skilled migration to the UK and its impacts on Africa. Report for the AUT and NATFHE. www. leeds met ac.uk/ibs/pri April 2005.

Oyekanwi, R. L., 2005. Collapse in Education system is our collective failure. The Guardian Sunday, October 30.

The Editorial, 2012., 2013 Budget and the Nigerian Education system. Education Affairs News Feb. W. P. S. 